\title{
MODERN EUROPEAN HISTORY
}


Astronomy

Australian History

Banking

Basic English Law

Basic Management

Biology

British Politics

Business Communication

Business Microcomputing

Catering Science

Chemistry

COBOL Programming

Commerce

Computer Programming

Computers

Data Processing

Economic and Social History

Economics

Electrical Engineering

Electronics

English Grammar

English Language

English Literature

Financial Accounting

French

French 2

German
Hairdressing

Italian

Italian 2

Japanese

Keyboarding

Marketing

Mathematics

Modern British History

Modern European History

Modern World History

Nutrition

Office Practice

Pascal Programming

Physics

Practical Writing

Principles of Accounts

Restaurant Service

Social Welfare

Sociology

Spanish

Spanish 2

Statistics

Statistics with your Microcomputer

Study Skills

Typewriting Skills

Word Processing 


\section{MASTERING}

\section{MODERN EUROPEAN}

\section{HISTORY}

STUART T. MILLER

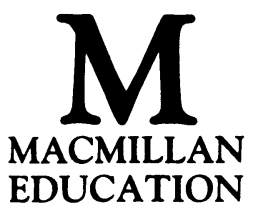


All rights reserved. No reproduction, copy or transmission of this publication may be made without written permission.

No paragraph of this publication may be reproduced, copied or transmitted save with written permission or in accordance with the provisions of the Copyright Act 1956 (as amended), or under the terms of any licence permitting limited copying issued by the Copyright Licensing Agency, 33-4 Alfred Place, London WC1E 7DP.

Any person who does any unauthorised act in relation to this publication may be liable to criminal prosecution and civil claims for damages.

First published 1988

Published by

MACMILLAN EDUCATION LTD

Houndmills, Basingstoke, Hampshire RG21 2XS

and London

Companies and representatives

throughout the world

Typeset by Tec Set Ltd, Wallington, Surrey

ISBN 978-0-333-41265-7

ISBN 978-1-349-19580-0 (eBook)

DOI 10.1007/978-1-349-19580-0

ISBN 978-0-333-41266-4 (Export Pbk) 


\section{CONTENTS}

List of Illustrations

List of Maps

List of Figures

Preface

Acknowledgements

Note on Names and Distances

$$
\begin{array}{r}
\text { xix } \\
\text { xxi } \\
\text { xxii } \\
\text { xxiii } \\
\text { xxv } \\
\text { xxvi }
\end{array}
$$

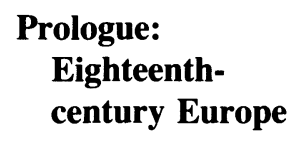

Prologue: century Europe

1 The French

Revolution
Introduction

The Ancien régime

'Prosperity by compulsion'

Economic changes

Enlightened despotism

Conclusion: 'The world upside down'

xxviii

xxviii

$\mathrm{xxx}$

xxxi

xxxii

xxxiii

1.1 The causes of the

French Revolution

1

1.2 The revolt of the nobility (1787-8)

1.3 The revolution of the lawyers (5 May-27 June 1789)

1.4 The revolt of the masses (14 July-5 October 1789)

1.5 Constitutional monarchy (October 1789-

September 1792)

1.6 The overthrow of the 6 monarchy (September 1792)

1.7 The popular revolution: democratic phase (September 1792-June 1793) 
1.8 The popular revolution: 9 dictatorship (June 1793-July 1794)

1.9 The republic of the Thermidorians (July 1794-November 1799) 14

1.10 The coup de Brumaire (1799)

1.11 Conclusion

2 The Napoleonic Era 1799-1815

3 The Concert of Europe 1815-30
2.1 The 'man of destiny'

2.2 Napoleon's rise to power

2.3 Domestic reforms (1800-3)

2.4 The renewal of war (1803-7)

2.5 The Grand Empire

2.6 The Continental System

2.7 The organisation of the Grand Empire

2.8 The fall of Napoleon

2.9 The final stage

2.10 The 'Hundred Days'

2.11 Conclusion

3.1 The legacy of the French Revolution

3.2 'A great European'

3.3 The Vienna Settlement 40

3.4 Assessment of the Vienna Settlement

3.5 Metternich's system

3.6 The Congress system

3.7 The Concert of Europe

3.8 'Back to a wholesome state'

3.9 Conclusion

4 The Age of

Revolutions 1815-48
4.1 Theories of revolution

4.2 Romanticism

4.3 Nationalism 
4.4 Liberalism

4.5 Socialism

4.6 Communications

4.7 'This great and dangerous plot'

4.8 Social theories

4.9 The peasantry

4.10 The 'labouring and dangerous classes' $\quad 60$

4.11 The middle classes

4.12 Weakness at the top 63

4.13 The accelerator 64

4.14 Conclusion 65

5 Restoration France 1815-48

5.1 The restoration of the

5.2 The failure of conciliation (1815-24) 70

5.3 The reign of Charles $X \quad 73$

5.4 The July Monarchy 74

5.5 The early problems of the régime

5.6 'France is bored' 77

5.7 Growing opposition $\quad 78$

$\begin{array}{lll}5.8 \text { Conclusion } & 79\end{array}$

6 Italy 1796-1848

6.1 A 'geographical expression'

6.2 The Napoleonic occupation

6.3 The era of the Secret Societies (1814-32) 85

6.4 Routes to unification

6.5 Mazzini and the Italian Republic

6.6 Liberal reformism

6.7 Gioberti and neo-

Guelphism

6.8 Charles Albert and

Piedmont

6.9 Conclusion 
7.1 'The Germanies' in 180095

7.2 The impact of the French Revolution and Napoleon

7.3 The Napoleonic Settlement of Germany 98

7.4 The Prussian revival 98

7.5 German nationalism 99

7.6 The German Confederation 102

7.7 The Vormärz (1815-48) 103

7.8 Economic development 104

7.9 Conclusion 106

8 The Habsburg Monarchy 1809-48
8.1 The Habsburg Monarchy

8.2 Threats to the dynasty 113

8.3 Metternich and the problems of the Habsburg Monarchy (1815-48)

8.4 The growth of opposition

8.5 Lower Austria

8.6 Bohemia

8.7 The South Slavs

8.8 Hungary

8.9 Conclusion

9 The Revolutions of 1848
I 'The Springtime of the Peoples'

9.1 Italy (January -March 1848)

9.2 France (February-April 1848)

9.3 Germany (March-April 1848)

9.4 The Habsburg

Monarchy

(March-May 1848)

II 'A troublesome

summer' 
$9.5 \quad$ Italy (March-July 1848) 131

9.6 France (April-June 1848)

9.7 Germany (April-June 1848)

9.8 The Habsburg Monarchy (May-October 1848) 135 III 'A disastrous winter'

9.9 Italy (July 1848-August 1849)

9.10 France (June 1848December 1851)

9.11 Germany (October 1848-September 1849)

9.12 The Habsburg Monarchy (October 1848-August 1849)

9.13 Conclusion

10 Imperial Russia 1801-81
10.1 Russia in the early nineteenth century

10.2 'The enigmatic Tsar' (1801-25)

10.3 The Decembrist revolt (1825)

10.4 Nicholas I and reaction (1825-55)

10.5 The development of opposition, (1836-54) 151

10.6 'The Epoch of Great Reforms'

10.7 The growth of opposition (1861-81)

10.8 Conclusion

11 The Eastern Question 11.1 The nature of the 1804-56
Eastern Question

160

11.2 The main episodes

(1821-56)

11.3 The Greek War of

Independence

(1821-32) 
11.4 The first Mehemet Ali crisis (1832-3) 164

11.5 The second Mehemet Ali crisis (1839-40) 165

11.6 The Crimean War 167

11.7 Conclusion 172

12 The Second French

12.1 The new régime

175

Empire 1852-70

12.2 The character of Napoleon III

12.3 'L'Empire, c'est la Paix'

12.4 The Crimean War and the Congress of Paris 181

12.5 The foundations of the Liberal Empire $\quad 181$

12.6 Liberal reforms (1860-1) 183

12.7 Imperial and foreign policy (1859-66) 183

12.8 The Liberal Empire 185

12.9 The Franco-Prussian War and the downfall of Napoleon III 185

12.10 Conclusion 187

13 The Unification of Italy 1850-71
14 The Unification of

Germany 1862-71
13.1 The effects of the revolutions of $1848 \quad 189$

13.2 The obstacles to unification

13.3 The transformation of Piedmont

13.4 Cavour and the unification of Italy

13.5 The process of Italian unification (1859-61) 195

13.6 'A single, indivisible Italy'

13.7 The completion of

$\begin{array}{lll} & \text { unification } & 201 \\ 13.8 & \text { Conclusion } & 201\end{array}$

14.1 The rise of Bismarck 205

14.2 Diplomatic events (1863) 
14.3 The Danish War (1864) 208

14.4 The Austro-Prussian War (1866) 208

14.5 The triumph of Bismarck 211

14.6 The background to the Franco-Prussian War 211

14.7 The Franco-Prussian

$$
\text { War (1870-1) }
$$

14.8 The consequences of the Franco-Prussian War 216

14.9 The process of unification

14.10 Varieties of unification 220

14.11 Conclusion

15 The New Imperialism $\quad 15.1$ The course of the New

$$
\text { Imperialism }
$$

15.2 The 'Scramble for Africa'

15.3 East and South-East Asia

15.4 The causes of the New Imperialism

15.5 Economic theories

15.6 An extension of 229 European diplomacy

230

15.7 The continuation of

$\begin{array}{lll} & \text { imperialism } & 232 \\ 15.8 & \text { Enabling factors } & 233 \\ 15.9 & \text { Conclusion } & 237\end{array}$

15.9 Conclusion

16 Bismarck and

International

Relations 1871-90
16.1 The objectives of Bismarck's foreign policy

16.2 The Dreikaiserbund

16.3 The Bulgarian crisis

$$
\text { (1875-8) }
$$

16.4 Bismarck's alliance

$$
\text { system (1879-82) }
$$

16.5 The decline of the

Bismarckian system (1882-90) 
16.6 The 'dropping of the pilot'

16.7 Conclusion

17 The Kingdom of Italy 1870-1915
18 Imperial Germany

$$
\text { 1871-1914 }
$$

17.1 'La Revolution manquée' 254

17.2 The problems facing

$$
\text { Italy } 255
$$

17.3 The 'parliamentary dictatorships' (1876-96)

17.4 Depretis and the political system (1876-87) 258

17.5 Crispi and radical nationalism (1887-96) 259

17.6 The threat to the parliamentary system (1896-1900)

17.7 'Giolittisme' (1903-14) 262

17.8 Conclusion 264

$18.1 \quad$ Economic growth (1871-1914) 265

18.2 The constitution of the Second Reich 267

18.3 The persistence of powerful privileged élites

18.4 The 'Iron Chancellor' 270

18.5 The Kulturkampf 271

18.6 A new alignment

(1879-90) 272

18.7 Germanisation of the national minorities 275

18.8 The Wilhelmine Era

18.9 Conclusion 276
19 The Third Republic 1871-1914
19.1 Post-war reconstruction 280 19.2 The constitution 281 
19.3 The Republic of the Republicans (1879-85) 282

19.4 Weaknesses of the parliamentary régime 286

19.5 Scandals and crises (1886-1906)

19.6 'The spring tide of Radicalism' (1899-1914)

19.7 The challenge from the extreme left

19.8 Conclusion

20 Imperial Russia 1881-1914
21 The Habsburg Monarchy 1849-1914
20.1 An era of reaction (1881-1905)

298

20.2 The economy

$$
\text { (1881-1905) }
$$

300

20.3 Agricultural stagnation 300

20.4 Industrial expansion 302

20.5 The development of opposition to Tsarism 304

20.6 The 'dress rehearsal' of (1905-6)

20.7 Stolypin and the Dumas (1906-7)

20.8 A period of domestic peace (1907-12)

20.9 Conclusion

21.1 A broad perspective

21.2 Centralised absolutism

21.3 A hiatus (1860)

21.4 The 'Schmerling System' (1861-5)

21.5 The Ausgleich (1867)

21.6 The Dual Monarchy

21.7 The Dual Monarchy

$$
\text { (1867-1908): Austria }
$$

(1867-1908): Hungary 324

21.8 Deadlock (1908-14)

21.9 Conclusion 
22 The Origins of the

First World War

1890-1914
23 The First World War and its Aftermath 1914-21
22.1

The Franco-Russian

Alliance (1894)

330

22.2 Terms of the FrancoRussian Alliance

331

22.3 The ending of British isolation (1893-1902) 332

22.4 The detaching of Italy from the Triple Alliance (1896-1902) 335

22.5 The Anglo-French rapprochement

22.6 The Anglo-Russian rapprochement

22.7 The Bosnian Annexation Crisis (1908)

22.8 The second Moroccan Crisis (1911)

22.9 The Balkan Wars (1912-13)

22.10 The outbreak of war 344

22.11 Conclusion 345

23.1 The conduct of the war (1914-18)

23.2 The domestic impact of the First World War

23.3 The Russian Revolution (1917)

23.4 The disintegration of the Dual Monarchy

23.5 The fall of the Hohenzollerns

23.6 The Versailles

Settlement

23.7 Other treaties (1919-21) 368

23.8 Conclusion 370

24.1 The League of Nations 374 24.2 The German Question 376 24.3 Reparations and war debts 
24.4 The 'cordon sanitaire'

379

24.5 The Geneva Protocol

(1924-5)

379

24.6 The 'Locarno

Honeymoon' (1925-9) 380

24.7 The Great Depression (1929-33)

381

24.8 The reversal of the

Treaty of Versailles (1933-7)

24.9 The Abyssinian War (1935-6)

24.10 Conclusion

25 Soviet Russia 1917-40 25.1 Consolidation of power

(November

1917-mid-1918)

389

25.2 War Communism

(mid-1918-March 1921)

25.3 The New Economic

Policy (March

1921-1928)

25.4 The struggle for power 393

25.5 The 'Third Revolution' 396

25.6 The Purges 400

25.7 The 'cult of personality' 402

25.8 Conclusion

403

26 Mussolini and Italy 1918-36

26.1 The vulnerability of Italy

26.2 The weakness of the political system

26.3 Mussolini and the

Fascist Party

26.4 The establishment of dictatorship (1922-5) 411

26.5 The Fascist State

26.6 Manipulation of public opinion

26.7 The economy

26.8 Conclusion 
27 The Weimar Republic and the Rise of Hitler 1919-39
28 The Road to War 1936-9
27.1 The Weimar régime

27.2 Perception of the Weimar Republic

27.3 The background of Adolf Hitler

27.4 The 'March on Berlin'

27.5 Weimar (1924-9)

27.6 The Nazi achievement of power (1929-33) $\quad 428$

27.7 The Nazi Revolution 430

27.8 The Gleichschaltung 433

27.9 Conclusion 435

28.1 The polarisation of

28.2 political views

28.3 The Anschluss (March 1938)

28.4 The Sudetenland Crisis (August-September 1938)

28.5 The destruction of Czechoslovakia (March 1939)

28.6 The outbreak of war (September 1939)

28.7 Conclusion 448 449

29.1 The Blitzkrieg

(September 1939-June 1940)

29.2 British resistance (June 1940-June 1941)

29.3 The onset of global war (June 1941-July 1942) 456

29.4 The Nazi New Order 458

29.5 Turning points (October 1942-January 1943)

29.6 The counter-invasion of Europe (January 1943-December 1944) 
29.7 The diplomacy of the

war

462

29.8 The end of the war with Japan

465

29.9 The costs of the War 465

29.10 Conclusion

466

30 Post-war Europe and the Cold War 1945-55

30.1 The preliminary government of Germany and Austria

30.2 The post-war settlements

30.3 The United Nations

30.4 The onset of the Cold

30.5 Post-war Europe

30.6 Soviet expansionism

30.7 The USA and

30.8 The German Question 480

30.9 Regional defence organisations

30.10 The Korean War (1950-3)

30.11 Conclusion

31 Western Europe 1953-86
31.1 The 'wind of change' 485

31.2 Strains within the western alliance

488

31.3 De Gaulle and the French revival

31.4 Control of the nuclear

31.5 The purposes of NATO 490

31.6 'Family conflicts'

491

31.7 The European Economic Community (EEC)

31.8 Conclusion 
32 The Communist Bloc

1945-79
32.1 The satellite empire

$$
\text { (1945-53) }
$$

499

32.2 Life after Stalin

501

32.3 Tensions within the Soviet bloc

504

32.4 Discontents and challenges

505

32.5 Poland (1956)

32.6 The Hungarian Revolution (1956)

32.7 'Twenty years of enlightenment'

32.8 The Czechoslovak Action Programme (1968)

32.9 Conclusion

510

33 International Relations 1953-87

33.1 The 'Thaw'

33.2 Challenges to peaceful coexistence'

33.3 The emergence of

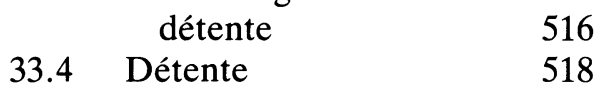

33.5 Disarmament and arms control

33.6 Conclusion

$34.1 \quad$ New perspectives

523

34 Breaking the mould:

34.2 The Polish Solidarity

Europe in the 1980s

526

528

34.4 The Gorbachev gambit 529

34.5 A 'lame duck'

presidency? 532

34.6 Arms limitation 534

34.7 Conclusion 537

Further Reading $\quad 539$

Index 


\section{ILLUSTRATIONS}

1.1 The Tennis Court Oath (20 June 1789)

1.2 The expropriation of the Church

1.3 Robespierre's government

2.1 The execution of the defenders of Madrid (1808) 29

2.2 The retreat from Moscow 31

2.3 The resurrection of Napoleon 34

4.1 Houndsditch (1875) 61

7.1 Blessing of the Lützow Free Corps (1813) 101

7.2 German economic and political advances 107

9.1 The King of Prussia salutes the dead 127

9.2 Frederick William IV (1848) 128

9.3 Metternich's flight 129

9.4 Exiles (1848) 130

9.5 Louis Napoleon takes the oath 139

10.1 Russian peasants at a well (1880s) 153

11.1 Officers of the 68th Regiment in the Crimea 169

11.2 French infantry in the Crimea 170

12.1 Censorship under the Second Empire 177

12.2 A vision on the way: 'Beware' 186

13.1 Napoleon III at Magenta 197

13.2 The battle of the Volturno, October $1860 \quad 199$

14.1 Making omelettes 212

14.2 Prussian troops trying to take the railway line between Nancy and Metz (1870)

14.3 The Parisian diet during the first siege of Paris 217

14.4 The acclamation of the Emperor in the Hall of Mirrors at Versailles

15.1 On the swoop!

15.2 Despise not your enemy! 235

16.1 Serbian troops on the march (1885) 250

18.1a,b Bismarck deals with the Liberals and Socialists 273-4

18.2 The Krupp cannon factory 277

19.1 Seize Mai $1877 \quad 283$

19.2 La dernière quille 288

22.1 Kaiser Wilhelm II in Tangier 337

$23.1 \quad$ Wollt ihr dieses? 353 


\section{ILLUSTRATIONS}

23.2 Daddy, what did YOU do in the Great War?

354

23.3 Destroy this mad brute. Enlist

355

24.1 The awful warning

386

$25.1 \mathrm{a}, \mathrm{b}$ The expunging of Trotsky from history

25.2 The USSR under Stalin

$395-6$

26.1 Black jerseys and black shirts

401

26.2 The Ballilla

408

26.3 Mussolini and the 'battle for grain'

413

$27.1 \mathrm{a}, \mathrm{b}$ Hitler in power

416

27.2 a,b Anti-Semitism

$431-2$

29.1 Liberators

$436-7$

29.2 Les menteurs de Berlin

461

30.1 See for yourself

463

31.1 Non!

477

32.1 Now they've bloomed, next year we shall have fruit 


\section{MAPS}

Fig. $2.1 \quad$ Europe in 1810

Fig. 3.1 Europe in 1815

Fig. 6.1 The states of Italy in 1815

Fig. 7.1 The German Confederation 96

Fig. 7.2 The Zollverein 105

Fig. 8.1 The Habsburg Monarchy in $1848 \quad 114$

Fig. 13.1 The unification of Italy (1859-71) 195

Fig. 14.1 The unification of Germany (1866-71) 210

Fig. 14.2a,b German railways (1850-80) 220-21

Fig. 15.1 The colonisation of Africa (1876-1914) 227

Fig. 16.1 The Balkans according to the Treaties of San Stefano and Berlin (1878) 245

Fig. 21.1 The nationalities of Austria-Hungary in $1914 \quad 323$

Fig. 22.1 The impact of the Balkan wars (1912-13) 343

Fig. 23.1 Europe in $1914 \quad 352$

Fig. 23.2 Europe in $1923 \quad 369$

Fig. 28.1 The expansion of Germany (1919-38) 444

Fig. 29.1 Europe in October $1942 \quad 457$

Fig. 31.1 The decolonisation of Africa since 1945

Fig. 34.1 Europe in the 1980s 524 


\section{FIGURES}

Fig. P.1 The relative contributions of agriculture and industry to the national product of the United Kingdom (1788-1907) xxxii

Fig. 12.1 The volume of horse power derived from steam engines in France (1830-75)

Fig. 17.1 The relative contributions of agriculture and industry to the Italian national product (1861-1910) 256

Fig. 18.1 The relative contributions of agriculture and industry to the German national product (1850-1910) 266

Fig. 19.1 The relative contributions of agriculture and industry to the French national product (1815-1909) 293

Fig. 19.2 Population growth in Germany and France (1850-1910)

Fig. 20.1 Population growth in Russia (1850-1910) 301

Fig. 20.2 The comparative densities of railway networks in Europe in 1913 303

Fig. 22.2 Steel production in Great Britain and Germany (1891-1911)

Fig. 24.1 The structure of the League of Nations

Fig. 25.1 Economic activity in the USSR (1928-35) and livestock numbers in the USSR (1916-70)

Fig. 27.1 The structure of the Nazi state 435

Fig. 30.1 The structure of the United Nations 


\section{PREFACE}

Like all textbooks, there is very little originality of content in Mastering Modern European History. The original ideas and interpretations have been carefully quarried from many of the books referred to in the Further Reading section, to whose authors I owe a general acknowledgement. The claim to originality on behalf of this book rests upon the following factors:

(i) A logical synthesis

There is a middle way between the Marxist view that there are preordained patterns in historical development and Henry Ford's claim that 'History is just one damn thing after another' (just a little less famous than his remark that 'History is bunk'). I have desperately avoided the antique 'There were 37 causes of the French Revolution' method of teaching, although I have used an enumeration system for convenience. Certainly in retrospect historical events are due usually to the interaction of several factors and do follow some sort of narrative pattern. I have thus used chronological accounts where necessary in combination with considered analyses of the component factors contributing to events.

(ii) Coverage of controversy

The work of the historian is not only the accumulation of data, but also its interpretation. History is therefore a subject full of controversy. There is an awful danger that a textbook can become a sort of exercise in name-dropping, and I have sometimes lapsed into this behaviour, but it is important that attention should be drawn to the main issues of controversial interpretations. On many occasions - as with the origins of the Second World War and of the imperialism of the late nineteenth century - I have deliberately taken time to consider theories and their interaction.

I have included selections of sample questions drawn from the reservoirs of a number of examination boards and these are a typical cross-section. A number of questions have been devised by myself, especially when the subject content of the book gets beyond the 1960s and begins to exceed the chronological limits of many examination syllabuses as they at present 
exist. I have deliberately not written the book as answers to questions, simply because this can cause structural problems. However, there is everything to be said for encouraging students to regard History as a vast complex of questions as to what happened, why it happened, and why it mattered. Most of the section and paragraph headings which I have used are easily equated with these fundamental questions.

The book is intended primarily as an introduction for those studying for a first examination in Modern European History. However, I believe that it will also provide a valuable guide and synthesis for those involved in courses at a higher level. Within both of these categories I include the growing volume of mature and part-time students handicapped by a belated return to study and a pressing shortage of time. I would also like to think that it is quite readable in its own right, and that the famous 'general reader' might browse through it.

My thanks are due to a number of people who contributed towards the completion of this book in one way or another. Peter Oates and Jon Finegold of Macmillan were pillars of friendly encouragement and advice. My wife, Constance, and my children Gillian and David 'endured' long periods of my silent furious scribbling and helped me in more ways than I can possibly itemise. Mrs Mary Milburn typed the manuscript expertly and without once expressing the despair she must have felt when confronted with a handwriting style which reached its peak at the age of 12 and then steadily degenerated. 


\section{ACKNOWLEDGEMENTS}

The author and publishers wish to thank the following who have kindly given permission for the use of copyright material:

Edward Arnold (Publishers) Ltd for an extract from Nantes au XIXe Siècle by Dr A Guepin quoted in Documents of European Economic History Vol. 1, The Process of Industrialization 1750-1870, ed. S. Pollard and C. Holmes.

Constable \& Company Ltd for an extract from Rhyme and Revolution in Germany by J. G. Legge, 1918.

Curtis Brown Group Ltd on behalf of C. \& T. Publications Ltd for a telegram to Harry Truman from Winston Churchill, 12 May 1945. Copyright (C) C. \& T. Publications.

J. M. Dent \& Sons Ltd for an extract from Sentimental Education by Gustave Flaubert translated by Anthony Grossmith, Everyman's Library, 1941.

Joint Matriculation Board, Oxford and Cambridge Schools Examination Board, University of Cambridge Local Examinations Syndicate and University of Oxford Delegacy of Local Examinations for questions from past examination papers.

Oxford University Press for extracts from The Diary of One of Garibaldi's Thousand translated by E. R. Vincent, 1962; Memoirs by von Moltkes quoted in The Origins of the War of 1914 by $\mathrm{L}$. Albertini, 1957; and Kaiser's speech, 15 February 1881, quoted in Documents in the Political History of the European Continent 1815-1939, ed. G. A. Kertesz, 1968.

Unwin Hyman Ltd for an extract from 'J'Accuse' by Emile Zola quoted in The Dreyfus Case by F. C. Conybeare, George Allen, 1898.

Every effort has been made to trace all the copyright-holders, but if any have been inadvertently overlooked the publishers will be pleased to make the necessary arrangement at the first opportunity. 


\section{NOTE ON NAMES}

\section{AND}

\section{DISTANCES}

I have followed certain conventions in referring to some of the states of Europe. First of all, though, a point should be made about the title of the book. Britain played a vital role in European history in the nineteenth and twentieth centuries due to her economic leadership until 1914, her recurrent interventions into European international relations, and her imperial activities. However I have tended to treat her very much as 'the offshore island' until the post-1945 period, when Britain became a member of various European organisations and especially the EEC. I have not attempted to deal with the internal affairs and development of Britain. For this latter, the reader is directed to the excellent volume Mastering Modern British History (Macmillan, 1984) by Norman Lowe. Also after 1945, it becomes increasingly difficult - and of questionable value - to try and segregate European from World history. I hope that I have achieved a reasonable compromise.

Apart from this, I have faced the usual problems of nomenclature in dealing with a number of states and I hope that the following explanation is adequate.

(i) The Habsburg Monarchy

The problem arises because the Monarchy included provinces called Upper Austria and Lower Austria. Nevertheless for convenience I have usually referred to 'Austria' or 'the Austrian Empire'. However, in a number of chapters where this policy could cause confusion I have used the titles 'Habsburg Monarchy' - and, after 1867, 'the Dual Monarchy' or 'Austria-Hungary: At least the First World War solved this problem! 
(ii) Germany

Before 1871 , I have occasionally employed the old-fashioned contemporary practice of talking of 'the Germanies'. The complexities of the membership of the German Confederation are explained in the relevant chapter.

(iii) The Ottoman Empire

Although I have used the proper title before 1914, I have often used the term 'Turkey' and spoken of 'the Turks', just as contemporaries did.

(iv) Piedmont

Technically, the correct title of the northernmost Italian kingdom was 'the Kingdom of Sardinia-Piedmont'. In keeping with usual practice, though, I have used the term 'Piedmont'.

(v) Russia

After 1917, I have tended to employ, as we do today, a number of titles interchangeably. 'Russia', 'the Soviet Union', 'Soviet Russia' and the 'USSR' all refer to the same state. In fact, technically, 'the Russian Socialist Soviet Republic' is only one - albeit the greatest - of the units of the USSR.

Any other confusion that might arise on this subject must be attributed entirely to my own carelessness.

(vii) Distances

Finally I have standardised distances on the mile (1 Kilometre $=0.62$ miles or 8 Kilometres $=5$ miles). 


\section{PROLOGUE:}

\section{EIGHTEENTH-CENTURY}

\section{EUROPE}

\section{INTRODUCTION}

The French Revolution is usually seen as the start of an era and the chief event to which can be related the main threads of European history in the nineteenth century. In fact - like other 'turning points' in history - the 'Great Revolution' was as much the end of a period as the beginning. Equally, Napoleon Bonaparte - the heroic 'superman' of the new Romantics - was in many respects the last and greatest of the old-style enlightened despots and mercantilists. The eighteenth century was characterised by a number of features:

(i) A stratified social system, with a rigid pattern of orders and groups surmounted by monarchy.

(ii) 'Mercantilism' or the commitment of state power to intervention in the economy to promote growth.

(iii) Economic changes associated with the use of manufacturing industries.

(iv) 'Enlightened Despotism', especially in the twenty-five years before the Revolution, which involved a recognition that royal power should be exercised to some extent in the interest of the subjects

\section{THE ANCIEN REGIME}

Although there were very considerable variations between the states of western Europe, worthwhile generalisations can still be made:

(a) The overwhelming predominance of peasant society

Society was essentially rural, and peasants were by far the largest social group. However, the status and conditions of the peasantry 
varied considerably throughout the continent, and even within states. There was a great difference between the lives of the free peasantry and the serfs, who were virtually the property of the landowner. In general, serfdom was more prevalent in eastern Europe and was especially marked in Russia despite the best intentions of Catherine II after her accession in 1762.

\section{(b) The influence of the aristocracy}

The aristocracy exercised very considerable local influence, officered the professional armies and monopolised the higher posts in the bureaucracies. They also had rights of jurisdiction and exemption from some types of taxation in every state other than Britain and the United Provinces. In addition, two other features are worth noting:

(i) Varying degrees of exclusiveness. In Britain, entry to the nobility was traditionally easier than elsewhere. Marriage and money could easily compensate for birth. As was once remarked in the sixteenth century: 'In England gentlemen be made good cheap'. The situation was very different as one moved eastwards. In France though, although the old military 'noblesse de l'epée' was dominant this had been supplemented by a more recent 'noblesse de la robe' drawn from prominent middle-class families. In general, there was a tendency in the eighteenth century for the nobility to respond to economic and social pressures by trying to assert its powers and privileges and restrict further creations.

(ii) The range of status and wealth within the nobility. There could be a vast difference between the great magnates and the small squires of, say, Poland, Hungary and England. In France, there were 250,000 'noblesse' but only 4000 genuine courtiers with any access to the king. In Spain, there were 500,000 nobles but only a hundred or so real 'grandees', as opposed to the myriads of petty 'hidalgos'.

\section{(c) The prevalence of monarchy}

There were vast differences between the size and structure of states. They ranged from large, centralised nation states like Britain and France, to the masses of very small principalities of Italy and 'the Germanies' - the 'swarm of gnats' as William Pitt the Younger called them - and the diverse collections of peoples and territories which made up states such as Prussia and Austria. The antique Holy Roman Empire ruled by the Habsburg dynasty and extending from northern Italy to the Netherlands and Prussia existed only in theory. All of 


\section{PROLOCUE}

these units were ruled, however, by some form of hereditary monarchy. No one seriously questioned this form of government. Only in the United Provinces was republicanism strong, and its decline as a state was a bad advertisement. It was also the lack of a strong monarchy which largely explained the ease with which Poland was partitioned between Prussia, Russia and Austria in the last quarter of the century. The strength of monarchy was further enhanced by the continuance of the traditional view of one's king as the 'father of his people', and the survival of the legend that monarchy was ordained by God and that kings, therefore, enjoyed a 'divine right'.

\section{'PROSPERITY BY COMPULSION'}

Since the late seventeenth century at least, governments had displayed a tendency towards 'mercantilism' - that is, towards the use of state power to build up economic wealth and, thereby, political and military might. The process was cyclical, because the acquired strength was in turn used to accumulate territory and colonies to expand the economy. The wars of the eighteenth century were power struggles between dynasties and rival empires rather than ideological disputes. In practice, mercantilism involved a welter of legislation and regulations to steer trade and production into definite channels by means of bounties, trade tariffs, prohibitions and monopolies. There was no clearly articulated theory of mercantilism, but in practice it suffered from two particular weaknesses.

\section{(a) The sacrifice of the interests of the consumer}

The main critic of the system was the Scottish economist Adam Smith, who in the Wealth of Nations (1776) insisted that 'consumption is the sole end and purpose of production'. Instead of countries specialising in their most efficient industries and trading freely in wider markets and at lower costs and prices they were caught up in 'beggar-my-neighbour' policies of protection and self-sufficiency.

\section{(b) The opposition of vested interests}

Mercantilism - with its complex rules, and large bureaucracies involved corruption, mismanagement and conflicts of interest between protected and preferred trades and those which were discriminated against. Smuggling - often on an enormous scale - was one response to tariffs and prohibitions. It was the attempts of the British government to tighten up the regulations against smuggling and 
evasion which stimulated the problems in the British North American colonies which led eventually to the American War of Independence in 1775. In general, it was the emerging middle classes (see below) which were most adversely affected by mercantilist restrictions.

\section{ECONOMIC CHANGES (see Fig. P.1.)}

The century saw a considerable increase in population. In Spain, population grew from 5 million in 1700 to 11 million in 1800 . In Russia it grew from 18 million in 1725 to 27 million in 1780 . In Europe as a whole it grew from 118 million in 1700 to 187 million in 1800. The reasons for this are not very clear. It was partly associated with a decline in the virulence of epidemic diseases. However, it was broadly related to a general increase in the standard of living.

\section{(a) Improved food supplies}

Better transport and some agricultural improvements reduced the recurrence of shortage crises. They did not totally disappear, however: in the 1770s and 1780s there were serious shortages and price increases. The fact that agriculture was the biggest sector of employment as well meant that a bad harvest not only affected the prices and increases of the agricultural sector but also had dire effects on urban employment.

\section{(b) Industrial development}

The Industrial Revolution in Britain was not matched on the continent. There were some large-scale factories such as the Van Robais textile factory at Abbeville which employed 3000 workers. But the bulk of manufacturing production, even in Britain, was still by means of the 'domestic system' and in small workshops although it was increasing significantly.

\section{(c) Urban growth}

One aspect of this rising prosperity was the expansion of the towns. In fact, only in the United Provinces, England and part of Italy was it more than a fraction of the total. The population of Paris was only 2 per cent of the total French population. Even so, the towns were influential because of their - often considerable - municipal rights and privileges and the power of the class of great financiers, bankers and merchants. In fact, the middle class was largely made up not of manufacturers or merchants but of small property owners, office holders and professional people. 
Fig. P.1 The relative contributions of agriculture and industry to the national product of the United Kingdom (1788-1907), percentages, the shaded columns represent industrial production

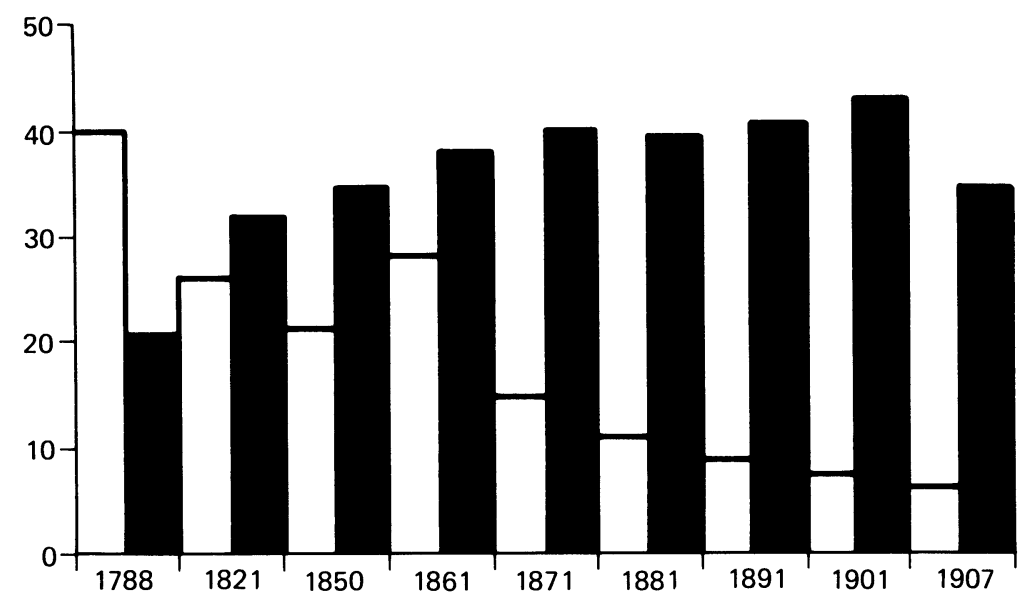

The changing proportions between the two sectors are typical of a developing economy. The pattern was most marked with the United Kingdom. What is also notable in this graph is the slackening off of growth in the Edwardian period. This reflects to some extent the tendency for the UK to derive more income from commercial and financial services.

Source: Based upon statistical information in C. Trebilcock, The Industrialisation of the Continental Powers 1780-1914 (Longman, 1981).

\section{ENLIGHTENED DESPOTISM}

Partly under the influence of the theories of intellectuals such as the Genevan, Jean Jacques Rousseau who, in his Social Contract (1762), argued that royal rule was a sort of two-way contract of duties, obligations and consultation between the monarchy and citizens, there was a tendency towards the use of monarchical power to improve the circumstances of the population. This was very marked in the last quarter of the century. Employing large bureaucracies and working to fairly coherent programmes a range of rulers such as Catherine II of Russia, Frederick the Great of Prussia and Joseph II of Austria pursued a range of social, legal, fiscal and administrative reforms. On the other hand, there were various threats and dangers associated with this. 


\section{(a) The exaggeration of despotism}

Given populations made up largely of ignorant and superstitious peasants and in a situation where there were all sorts of obstacles arising from the existence of masses of local privileges and rights, bad communications and a diversity of dialects, the operation of enlightened government involved centralisation and the employment of a very strong hand which provoked resentment.

\section{(b) The resistance of conservative forces}

Joseph II's reign (1782-90) was an extreme example, but the vested conservative interests he antagonised existed all over Europe. His attempts to end their tax exemptions and abolish serfdom infuriated the aristocracy and the Magyar squires. Attempts to reduce the excessive influence and power of the Catholic Church provoked devout Catholics. Only the opportune death of Joseph II in 1790 removed the danger of a revolution in Hungary.

\section{(c) The theoretical implications}

The acceptance of the need to use power in the interests of the population also implied that it could be resisted rightfully if this 'contract' was broken. Revolutionaries could argue that they were acting in self-defence and as conservatives against misuse of royal power, and so attract support from moderates.

\section{CONCLUSION: 'THE WORLD UPSIDE DOWN'}

When the defeated troops of General Cornwallis marched out of Yorktown in 1781 to the cynical strains of the most popular song of the day the situation was somewhat exaggerated. The American colonists - like the Magyar squires - were no social revolutionaries. Only on occasion in the eighteenth century - as in bread riots and the vicious Gordon Riots in London in 1780 - did the lower classes and the feared 'mob' emerge as a force to be reckoned with. However once the ball of revolution has started to roll, it is not easy to control or stop. The 'Atlantic Revolution' had started in North America in the prosperous British colonies. Thousands of European troops who had been involved in the war, including the young Marquis de Lafayette, returned to Europe after 1783. By the 1780s conditions were favourable to revolution in a number of European states. It was in France where all of the main ingredients were assembled at the ideal moment. 